\title{
Understanding the mechanisms behind high glacial productivity in the southern Brazilian margin
}

\author{
Rodrigo da Costa Portilho-Ramos ${ }^{1,2}$, Tainã Marcos Lima Pinho ${ }^{2,3}$, Cristiano Mazur Chiessi ${ }^{3}$, and \\ Cátia Fernandes Barbosa ${ }^{4}$ \\ ${ }^{1}$ MARUM - Center for Marine Environmental Sciences, University of Bremen, Leobener Strasse, 28359 Bremen, Germany \\ ${ }^{2}$ Institute of Geosciences, University of São Paulo, Rua do Lago 562, CEP05508-080, São Paulo, Brazil \\ ${ }^{3}$ School of Arts, Sciences and Humanities, University of São Paulo, Rua Arlindo Bettio 1000, \\ CEP03828-000, São Paulo, Brazil \\ ${ }^{4}$ Departamento de Geoquímica, Universidade Federal Fluminense, Rua Outeiro São João Baptista S/N, \\ CEP24020-141, Niterói, Brazil
}

Correspondence: Rodrigo da Costa Portilho-Ramos (rcpramos@marum.de)

Received: 9 August 2018 - Discussion started: 20 August 2018

Revised: 9 April 2019 - Accepted: 8 May 2019 - Published: 27 May 2019

\begin{abstract}
This study explores the mechanisms behind the high glacial productivity in the southern Brazilian margin (SBM) during the last $70 \mathrm{kyr}$ using planktonic foraminifera assemblage and subsurface temperature information derived using the modern analogue technique. We show that enhanced glacial productivity was driven by the synergy of two mechanisms operating in different seasons: (i) enhanced productivity in the upwelling region during short austral summer events; and (ii) the persistent presence of the Plata Plume Water (PPW) due to prolonged austral winter conditions. We suggest that the upwelling systems in the southern Brazilian margin were more productive during the last glacial period due to the enhanced Si supply for diatom production by highSi thermocline waters preformed in the Southern Ocean. We hypothesize that orbital forcing did not have a major influence on changes in upwelling during the last glacial period. However, the more frequent northward intrusions of the Plata Plume Water were modulated by austral winter insolation at $60^{\circ} \mathrm{S}$ via changes in the strength of alongshore southwesterly winds. After the Last Glacial Maximum, the reduced Si content of thermocline waters decreased upwelling productivity, while lower austral winter insolation decreased the influence of the Plata Plume Water over the southern Brazilian margin, reducing regional productivity.
\end{abstract}

\section{Introduction}

Continental margins are regions of relatively high biological productivity and long-term carbon storage due to high nutrient flux (i.e., continental discharge and upwelling) and shallow seafloor depths (i.e., interception of sinking particulate organic matter) (Bianchi et al., 2005; Wang et al., 2015; Abrantes et al., 2016; Ito et al., 2016; Brandini et al., 2018). The high biological productivity and exportation of particulate organic carbon to the seafloor, the so-called "biological pump" (Turner, 2015), play a paramount role in removing $\mathrm{CO}_{2}$ from the atmosphere (Bianchi et al., 2005; MullerKarger et al., 2005). It is estimated that ca. $0.06 \mathrm{Pg} \mathrm{C} \mathrm{yr}^{-1}$ is buried in continental margins, accounting for $>40 \%$ of the carbon storage in the oceans (Muller-Karger et al., 2005). In contrast to this drawdown, the upwelling of $\mathrm{CO}_{2}$-rich thermocline waters along continental margins can release $\mathrm{CO}_{2}$ to the atmosphere (Bianchi et al., 2005; Ito et al., 2016). Thus, continental margins have a great potential with respect to modulating the drawdown and emission of atmospheric $\mathrm{CO}_{2}$, influencing the Earth's climate system.

The southwestern Atlantic (southern Brazilian margin - SBM) is generally an oligotrophic area bathed by the nutrient-poor, warm, salty, tropical waters of the Brazil Current (BC) (Fig. 1). However, upwelling zones and riverine discharge inject nutrients into the photic zone (Campos et al., 2000, 2013; Garcia and Garcia, 2008; Möller et al., 2008; Brandini et al., 2018) resulting in confined areas and sea- 

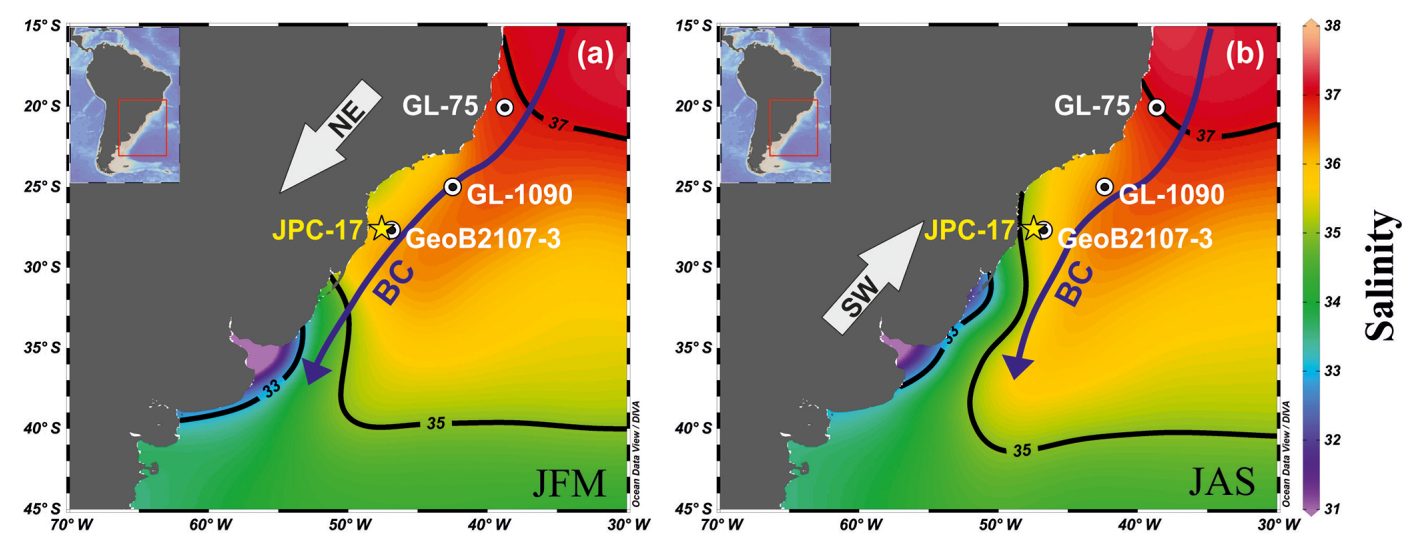

Figure 1. Surface salinity in the southwestern Atlantic Ocean (Locarnini et al., 2010) during (a) austral summer (December-February; DJF) and (b) winter (June-August; JJA) showing the location of cores JPC-17 (27 $53^{\prime} \mathrm{S}, 46^{\circ} 55^{\prime} \mathrm{W}$; this study), GeoB2107-3 (27 $17^{\prime} \mathrm{S}, 46^{\circ} 45^{\prime} \mathrm{W}$;

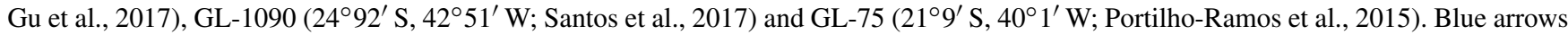
indicate the western boundary Brazil Current $(\mathrm{BC})$ and the gray arrows show the regional prevailing alongshore wind direction (northeast NE and southwest - SW). The figure was created using the Ocean Data View software (ODV; version 4.7.10; https://odv.awi.de/, last access: 20 March 2018).

sons with higher concentrations of phytoplankton and zooplankton biomass (Brandini et al., 2014; Rodrigues et al., 2014). During austral summer, upwelling zones are intensified due to the prevailing alongshore northeasterly winds and the cyclonic meanders of the $\mathrm{BC}$ induced by the interaction of the current with the morphology of the continental margin (Campos et al., 2000; Castelao et al., 2004; Aguiar et al., 2014). Winter conditions of vigorous alongshore southwesterly winds and a relatively weakened $\mathrm{BC}$, allow the northward intrusion of low-salinity waters from the Plata River along the SBM (Garcia and Garcia, 2008; Möller et al., 2008). Both processes increase local productivity and lead to distinct changes in planktonic community (Brandini et al., 2014; Rodrigues et al., 2014), which are preserved in seafloor sediments and can be used to reconstruct changes in productivity in the SBM over time (Portilho-Ramos et al., 2015; Gu et al., 2017; Lessa et al., 2017).

Previous paleoceanographic studies provide evidence of an extremely intense primary productivity in the SBM probably related to an upwelling system during part of Marine Isotope Stage 5 ( 90-130 kyr) forced by strengthened northeasterly winds and the BC (Portilho-Ramos et al., 2015; Lessa et al., 2017). During the last glacial period (Marine Isotope Stages 2-4, 11.7-71 kyr), primary productivity weakened but was still significantly higher than that occurring in the Holocene (Portilho-Ramos et al., 2015). It has been suggested that the upwelling systems of the SBM were reduced during the last glacial period, and may have been limited to short intervals of the austral summer due the prolonged winter-like conditions of prevalent alongshore southwesterly winds and frequent cold front passages (Portilho-Ramos et al., 2015). However, the high abundance of eutrophic dinoflagellate cysts suggests increased primary productivity in the SBM during specific intervals of the last glacial period
(Gu et al., 2017). These high productivity periods would be triggered by the input of local (i.e., Itajaí River) and remote riverine nutrient-rich freshwater (i.e., Plata River plume) $(\mathrm{Gu}$ et al., 2017). Additionally, a recent study proposed that the periods of expansion and contraction of the upwelling zones of the SBM are modulated by eccentricity (Lessa et al., 2017), providing yet another mechanism to explain the evolution of primary productivity in the SBM. In summary, these studies show that different oceanographic mechanisms may have triggered high primary productivity in the SBM over time. These mechanism are, however, poorly understood.

Here we used planktonic foraminifera assemblage records and associated subsurface temperature reconstructions derived using the modern analogue technique (MAT) from piston core JPC-17 $\left(27^{\circ} 52.73^{\prime} \mathrm{S}, 46^{\circ} 55.25^{\prime} \mathrm{W}\right)$ to understand the paleoceanographic processes controlling changes in biological productivity in the SBM over the last $70 \mathrm{kyr}$. The comparison of our results to previously published records from the SBM allowed us to recognize two different mechanisms modulating past productivity changes over the last glacial-interglacial cycle.

\section{Regional setting}

The SBM is an oligotrophic margin under the influence of warm $\left(\geq 25^{\circ} \mathrm{C}\right)$, salty ( $\geq 35 \mathrm{psu}$ ) Tropical Water that flows southward within the BC (Fig. 1). Interactions of the BC with the morphology of the margin (i.e., changes in the orientation of the margin and the presence of a barrier represented by the Abrolhos Bank) generates cyclonic meanders and eddies that bring cold $\left(\leq 20^{\circ} \mathrm{C}\right)$, nutrient-rich thermocline waters (South Atlantic Central Water - SACW) to shallower depths where they are subjected to alongshore northeasterly winds (Campos et al., 2000; Rodrigues and Lorenzzetti, 2001; Castelao 
et al., 2004; Aguiar et al., 2014). Once over the shelf, wind stress and the Ekman dynamics bring the SACW to the surface creating mature upwelling zones in the SBM (Castelao et al., 2004; Aguiar et al., 2014). These processes boost biological productivity in specific portions of the SBM such as off Vitória $\left(\sim 18^{\circ} \mathrm{S}\right)$, Cabo Frio $\left(22-23^{\circ} \mathrm{S}\right)$ and Cape Santa Marta (27-29 $\mathrm{S}$ ) during the austral summer (Fig. 1). Marine sediment core JPC-17 investigated in this study was collected off Cape Santa Marta (Fig. 1).

In the vicinity of Cape Santa Marta, local productivity is also enhanced by the injection of nutrients from the freshwater discharge of local (i.e., Itajaí River) and remote (i.e., Plata River and Patos/Mirim Lagoon complex) sources (Garcia and Garcia, 2008; Möller et al., 2008). During the summer (Fig. 1a), the upwelling favorable northeasterly winds and the strong $\mathrm{BC}$ block the northward penetration of the Plata Plume Water (PPW) (at ca. $32^{\circ} \mathrm{S}$ ) (Möller et al., 2008; Campos et al., 2013). During austral winter (Fig. 1b), the weakened $\mathrm{BC}$ and the prevailing alongshore southwesterly winds increase the northward intrusion (up to ca. $27^{\circ} \mathrm{S}$ ) of the nutrient-rich, cold $\left(\leq 18^{\circ} \mathrm{C}\right)$, low salinity $(\leq 33.5 \mathrm{psu})$ PPW (Möller et al., 2008; Campos et al., 2013).

Both upwelling and freshwater inject large amounts of nutrients into the oligotrophic SBM, seasonally modulating the biological productivity as well as the plankton community in the region (Garcia and Garcia, 2008; Rodrigues et al., 2014). In the vicinity of the Cape Santa Marta, diatoms are the dominant group of phytoplankton, accounting for $29 \%-90 \%$ of phytoplankton and $31 \%-90 \%$ of the carbon biomass during the summer upwelling, whereas dinoflagellates dominate the phytoplankton during the winter intrusion of the PPW (Brandini et al., 2014).

\section{Material and methods}

Piston core KNR159-5-17JPC $\left(27^{\circ} 52,73^{\prime} \mathrm{S}, 46^{\circ} 55,25^{\prime} \mathrm{W}\right)$ recovered $15 \mathrm{~m}$, from which the uppermost $350 \mathrm{~cm}$ was investigated in this study. The core was raised from a water depth of $1627 \mathrm{~m}$ during R/V Knorr cruise 159-5 from Woods Hole Oceanographic Institution (WHOI, USA) (Fig. 1). The uppermost $350 \mathrm{~cm}$ of the core consisted of dark gray carbonate sediments. This section was sampled continuously every $10 \mathrm{~cm}$, and $2 \mathrm{~g}$ of sediment per sample was washed using a $62 \mu \mathrm{m}$ sieves.

\subsection{Planktonic foraminifera assemblage}

Planktonic foraminifera from core JPC-17 were dry picked from the $>150 \mu \mathrm{m}$ size fraction and quantified in relative abundances from splits containing more than 300 specimens per sample. The taxonomy was based on Stainforth et al. (1975). We assumed the effect of dissolution in our planktonic foraminiferal faunal composition to be negligible as core JPC-17 was collected at a water depth of $1627 \mathrm{~m}$, well above the modern and glacial lysocline (Volbers and Hen- rich, 2004). Here we do not distinguish between the white and pink varieties of Globigerinoides ruber, and also counted Globigerinoides sacculifer and Globigerinoides trilobus together as G. sacculifer as they are genetically the same species (André et al., 2013). Considering the taxonomic ambiguity involved with distinguishing the small (with respect to organism size, i.e., $\leq 250 \mu \mathrm{m}$ ) specimens of Globigerinella calida and Globigerinella siphonifera (de Vargas et al., 2002), we counted them together as G. siphonifera.

\subsection{Subsurface temperature reconstruction}

We reconstructed subsurface temperatures at a water depth of $100 \mathrm{~m}$ using the modern analog technique (MAT) following Portilho-Ramos et al. (2015). The MAT was performed on the $\mathrm{C} 2$ software (Juggins, 2007), and the basic assumption was that the temperature of ambient seawater is the primary control on foraminiferal assemblages (Morey et al., 2005). The planktonic foraminiferal calibration dataset used here comprises 1052 surface samples from the Atlantic Ocean: from these samples, 891 were previously published in Kucera et al. (2005a) and 161 from North Atlantic eastern boundary upwelling zones were previously published in Salgueiro et al. (2014). The modern annual temperature values at a water depth of $100 \mathrm{~m}$ from WOA 2009 (Locarnini et al., 2010) were extracted and used to calibrate the MAT. For the MAT transfer function, the squared chord distance was applied as a similarity measure. Additionally, when reconstruction results were evaluated, the weighted mean of the best 10 modern analogs was used (Kucera et al., 2005b). Using the leave-oneout cross-validation method, the root-mean-square error of prediction of the transfer function was $0.95^{\circ} \mathrm{C}\left(R^{2}=0.98\right)$.

\subsection{Age model}

An age model for core JPC-17 has been previously published on the basis of calibrated radiocarbon $\mathrm{AMS}{ }^{14} \mathrm{C}$ ages, $\delta^{18} \mathrm{O}$ in both planktonic and benthic foraminifera as well as regional planktonic foraminifera biostratigraphy (Portilho-Ramos et al., 2014a; Tessin and Lund, 2013). Reversals in radiocarbon ages from ca. 16 to 21 calibrated kiloannum before present (kacalBP; i.e., $1950 \mathrm{AD}$ ) were detected by Tessin and Lund (2013). These authors excluded four radiocarbon ages (i.e., 50, 54, 58 and $82 \mathrm{~cm}$ core depth) from 17 dated samples from core JPC-17 due to reversals (Table 1). The radiocarbon age obtained at $56 \mathrm{~cm}$ from Portilho-Ramos et al. (2014a) is placed within this interval and also seems to be reversed. Considering these age reversals, the chronology of the JPC-17 core was improved using the R script "Bacon" version 2.2, which uses Bayesian statistics to reconstruct accumulation histories for sedimentary deposits and considers a Student $t$ model to address outlying (reversed) ages (Blaauw and Christen, 2011). Thus, as explained by Blaauw and Christen (2011), Bacon version 2.2 is not affected by outlying ages. For the upper $190 \mathrm{~cm}$ of core JPC-17, all AMS 
Table 1. Chronology of core JPC-17 obtained by accelerator mass spectrometry (AMS) ${ }^{14} \mathrm{C}$ dating on planktonic foraminifera shells (Tessin and Lund, 2013; Portilho-Ramos et al., 2014a) and stable oxygen isotope $\left(\delta^{18} \mathrm{O}\right)$ tie points tuned to the LS16 stack from Lisiecki and Stern (2016).

\begin{tabular}{|c|c|c|c|c|c|c|c|c|}
\hline $\begin{array}{l}\text { Depth } \\
\text { (cm) }\end{array}$ & $\begin{array}{r}{ }^{14} \mathrm{C} \text { age } \\
\text { (years) }\end{array}$ & $\begin{array}{r}1 \sigma \text { error } \\
(\text { years })\end{array}$ & $\begin{array}{r}\text { Calibrated age } \\
(\text { ka cal BP })\end{array}$ & $\begin{array}{r}1 \sigma \text { error } \\
(\text { years })\end{array}$ & Notes & $\begin{array}{r}{ }^{\delta^{18} \mathrm{O}} \\
\text { tie points }\end{array}$ & $\begin{array}{r}\text { Estimated } \\
\text { error }\end{array}$ & Reference \\
\hline 10 & 4140 & 80 & 4228 & 283 & & & & Tessin and Lund (2013) \\
\hline 18 & 6970 & 20 & 7463 & 201 & & & & Tessin and Lund (2013) \\
\hline 26 & 9895 & 25 & 10784 & 233 & & & & Tessin and Lund (2013) \\
\hline 30 & 10555 & 25 & 11795 & 298 & & & & Tessin and Lund (2013) \\
\hline 34 & 11955 & 30 & 13454 & 195 & & & & Tessin and Lund (2013) \\
\hline 38 & 12870 & 30 & 14550 & 341 & & & & Tessin and Lund (2013) \\
\hline 42 & 13650 & 35 & 16001 & 390 & & & & Tessin and Lund (2013) \\
\hline 50 & 4190 & 15 & 4281 & 264 & Reversal & & & Tessin and Lund (2013) \\
\hline 54 & 14080 & 35 & 16569 & 338 & & & & Tessin and Lund (2013) \\
\hline 56 & 10000 & 60 & 10967 & 147 & Reversal & & & Portilho-Ramos et al. (2014) \\
\hline 58 & 10990 & 35 & 12371 & 273 & Reversal & & & Tessin and Lund (2013) \\
\hline 66 & 10790 & 25 & 12091 & 273 & Reversal & & & Tessin and Lund (2013) \\
\hline 74 & 18010 & 100 & 20922 & 282 & & & & Tessin and Lund (2013) \\
\hline 82 & 16120 & 80 & 18994 & 199 & Reversal & & & Tessin and Lund (2013) \\
\hline 90 & 18100 & 60 & 20975 & 282 & & & & Tessin and Lund (2013) \\
\hline 98 & 19020 & 70 & 22074 & 292 & & & & Tessin and Lund (2013) \\
\hline 190 & 32550 & 270 & 37946 & 312 & & & & Portilho-Ramos et al. (2014) \\
\hline 260 & & & & & & 57614 & 3870 & This study \\
\hline 350 & & & & & & 70000 & 2260 & This study \\
\hline
\end{tabular}

${ }^{14} \mathrm{C}$ ages (Table 1) were calibrated using the IntCal13 calibration curve (Reimer et al., 2013) with a reservoir correction age of $400 \pm 100$ years ( $1 \sigma$ error). For the core section that extrapolates the radiocarbon range (i.e., $191-350 \mathrm{~cm}$ ), two additional tie points (Table 1) were obtained by aligning the benthic foraminifera stable oxygen isotopes $\left(\delta^{18} \mathrm{O}\right)$ record from JPC-17 to benthic $\delta^{18} \mathrm{O}$ of nearby core GL1090 (Santos et al., 2017) (Fig. 1) and to the intermediatedepth South Atlantic benthic $\delta^{18} \mathrm{O}$ stack LS16 (Lisiecki and Stern, 2016) using the AnalySeries 2.0.5.2 software (Paillard et al., 1996) (Fig. 2). The benthic $\delta^{18} \mathrm{O}$ curve from JPC-17 is a combination of published Cibicidoides spp. (Tessin and Lund, 2013) and unpublished Cibicidoides spp. $\delta^{18} \mathrm{O}$ provided by WHOI (Fig. 2). The latest data follow the methodology applied in Curry and Oppo (2005). Error estimations of the $\delta^{18} \mathrm{O}$ tie points followed Santos et al. (2017), which take into account the mean resolution of the JPC-17 benthic $\delta^{18} \mathrm{O}$ record around the tie-point depth, the mean resolution of the reference curve around the tie-point age, a matching error visually estimated when defining tie points and the absolute age error of the timescale used for the reference record. In addition to the default parameters of the software, the following settings were used: mem.mean $=0.4$, acc . shape $=0.5$. and t.a $=9 /$ t. $b=10$. A total of 10000 age-depth realizations were used to calculate the median age and the $1 \sigma$ analytical uncertainty at a $5 \mathrm{~mm}$ resolution (Fig. 2b). The chronology of core JPC-17 was additionally supported by planktonic foraminifera biostratigraphy (Ericson and Wollin,
1968; Portilho-Ramos et al., 2014b), where the presence of Globorotalia menardii and the low abundance of Globorotalia inflata indicate Biozone $\mathrm{Z}$ (Holocene), whereas the absence of G. menardii and the high abundance of G. inflata characterize the glacial Biozone Y (last glacial period) (Fig. 2).

\section{Results}

In contrast to a previous chronology (Portilho-Ramos et al., 2014a), the new age model for the upper $350 \mathrm{~cm}$ of core JPC-17 spans the last ca. $70 \mathrm{kyr}$ (Fig. 2). The benthic oxygen isotope records from core JPC-17 display a clear glacial-interglacial pattern, which is comparable to the benthic $\delta^{18} \mathrm{O}$ record of nearby core GL-1090 as well as that of the intermediate-depth South Atlantic benthic $\delta^{18} \mathrm{O}$ stack LS16 (Lisiecki and Stern, 2016) (Fig. 2).

The planktonic foraminifera assemblage is composed of 28 species and subspecies. The following six species accounted for more than $70 \%$ of total planktonic assemblage: G. ruber (39\%), Globigerina glutinata (13\%), G. bulloides $(11.2 \%)$, G. inflata $(8.8 \%)$, G. sacculifer (5\%) and G. siphonifera $(2.5 \%)$. The abundance of $G$. menardii $(0.7 \%)$, Pulleniatina obliquiloculata $(0.3 \%)$, Orbulina universa $(0.3 \%)$, Globorotalia crassaformis $(0.3 \%)$, Neogloboquadrina dutertrei $(5.5 \%)$ and Globorotalia truncatulinoides $(3.9 \%)$ were published in Portilho-Ramos et al. (2014a). 


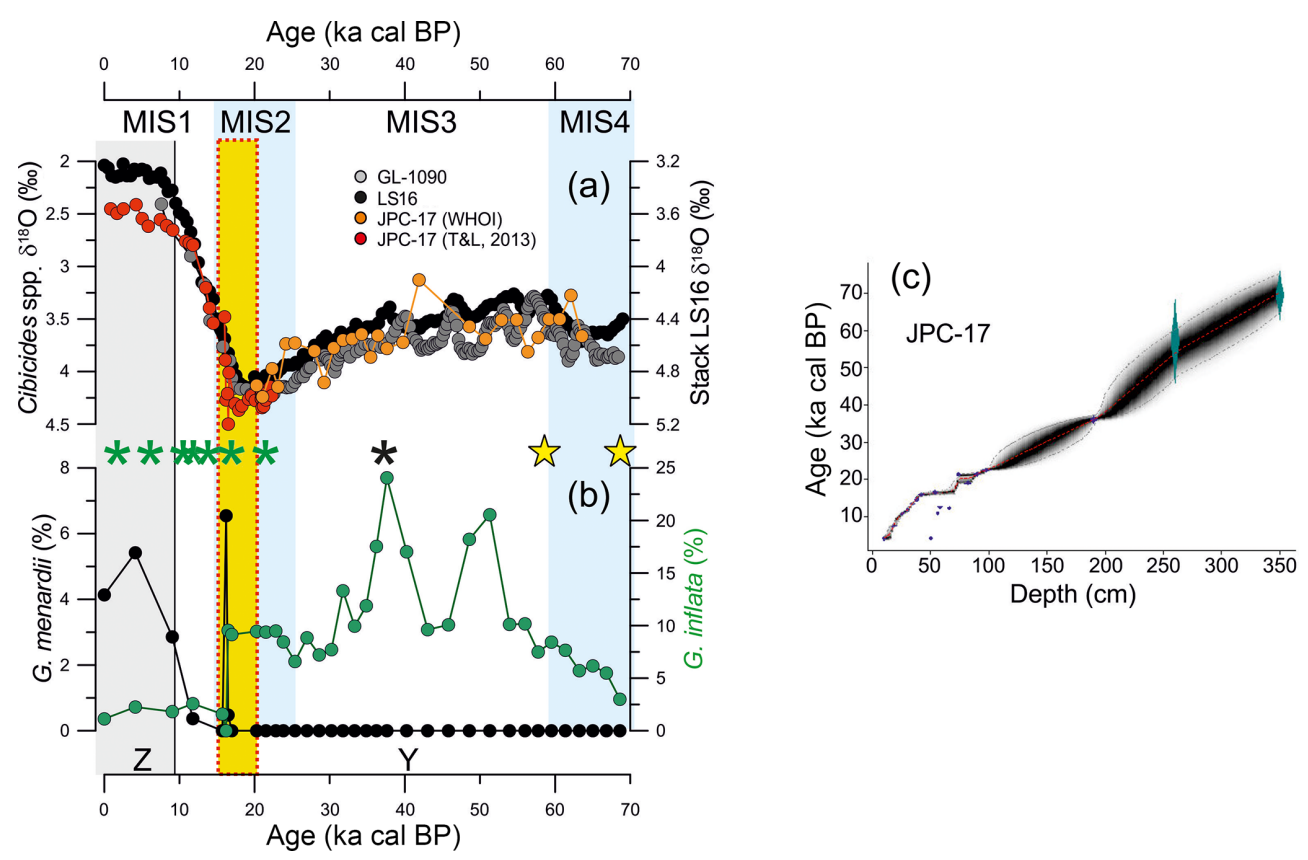

Figure 2. Age model of core JPC-17. (a) Comparison between the benthic foraminifera $\delta^{18} \mathrm{O}$ record of JPC-17 - composed of published Cibicidoides spp. (Tessin and Lund, 2013; T\&L, 2013) and unpublished Cibicidoides spp. data from Woods Hole Oceanographic Institution (WHOI) - to the benthic foraminifera $\delta^{18}$ O record of core GL-1090 (Santos et al., 2017) as well as to the intermediate-depth South Atlantic benthic $\delta^{18} \mathrm{O}$ stack LS16 (Lisiecki and Stern, 2016). Asterisks represent the calibrated radiocarbon ages published in (green) Tessin and Lund (2013) and (black) Portilho-Ramos et al. (2014b), whereas yellow stars represent the $\delta^{18} \mathrm{O}$ tie points shown in Table 1. (b) Abundance of the main biostratigraphical planktonic foraminifera species Globorotalia menardii and Globorotalia inflata from core JPC-17. Marine Isotopic Stages 1-4 (MIS1-4; MIS2 and MIS4 indicated by vertical blue bars) are shown at the top, whereas "Z" (vertical grey bar) and "Y" in the bottom correspond to biostratigraphical biozones from Ericson and Wollin (1968). (c) Age-depth model based on Bacon v. 2.2 (Blaauw and Christen, 2011). The symbols represent the positions of the calibrated AMS ${ }^{14} \mathrm{C}$ ages benthic $\delta^{18} \mathrm{O}$ tie points listed in Table 1 . Error estimations of the $\delta^{18} \mathrm{O}$ tie points follow Santos et al. (2017) and take into account the mean resolution of the JPC-17 benthic $\delta^{18} \mathrm{O}$ record around the tie-point depth, the mean resolution of the reference curve around the tie-point age, a matching error visually estimated when defining tie points and the absolute age error of the timescale used for the reference record. The vertical yellow bar marks the interval with reversed radiocarbon ages listed in Table 1.

In general, the distribution of the most abundant species follows the glacial-interglacial pattern over the last $70 \mathrm{kyr}$ (Fig. 3). The abundance of the non-spinose species G. bulloides and $G$. inflata were higher during the last glacial period (mean of $12 \%$ and $9.6 \%$, respectively) and lower during the Holocene (mean of $4.6 \%$ and $\sim 2 \%$, respectively; Fig. 3a, b, respectively). In contrast, the abundance of spinose species displayed the opposite behavior. The abundance of G. ruber ranged from $25 \%$ to $50 \%$ (mean of $39 \%$ ) during the glacial and increased after $40 \mathrm{kacal} \mathrm{BP}$ towards the Holocene (mean of 47; Fig. 3c). The abundance of G. sacculifer and G. siphonifera display similar patterns (Fig. 3d, e, respectively), and ranged between $1.6 \%$ and $10.4 \%$ and $0 \%$ and $7.6 \%$, respectively, with higher abundance during the postglacial interval (mean of $7.5 \%$ and $6.9 \%$, respectively).

The temperature at a water depth of $100 \mathrm{~m}$ derived from MAT ranged from 16 to $21.3{ }^{\circ} \mathrm{C}$ over the last $70 \mathrm{kyr}$ with lower temperatures recorded during the glacial $\left(16-20.3{ }^{\circ} \mathrm{C}\right)$ in comparison with the Holocene $\left(\sim 21^{\circ} \mathrm{C}\right)$ (Fig. 3f). A pro- nounced warming trend is observed after $30 \mathrm{ka}$ cal BP toward the Holocene.

\section{Discussion}

The planktonic foraminifera G. bulloides is a non-spinose surface-dwelling species generally inhabiting cold regions with high phytoplankton biomass that are typically associated with upwelling zones (Sautter and Thunell, 1991; Mohtadi et al., 2007; Lessa et al., 2014). Thus, high abundances of G. bulloides in marine sediments from regions potentially affected by upwelling have been widely used as an upwelling indicator (Peeters et al., 2002; Godad et al., 2011), including the SBM upwelling zones (Portilho-Ramos et al., 2015; Lessa et al., 2017). The last glacial abundance of G. bulloides in core JPC-17 (8\%-18\%; Fig. 3a) closely matches abundances found in surface sediments from the Cabo Frio upwelling (10\%-20\%) (Lessa et al., 2014), suggesting the occurrence of a sustained upwelling off Cape Santa Marta in the SBM. It also closely matches glacial 


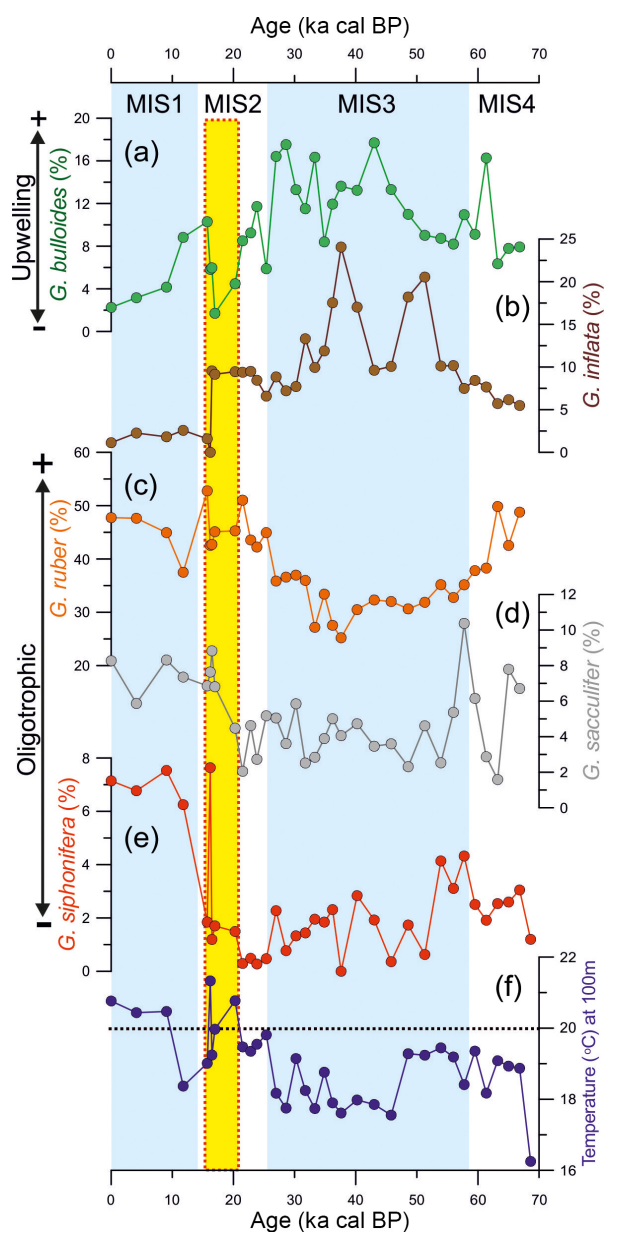

Figure 3. Relative abundance of planktonic foraminifera species and reconstructed subsurface temperature ( $100 \mathrm{~m}$ water depth) from core JPC-17 over the last 70 kyr. (a) Relative abundance of Globigerina bulloides, (b) Globorotalia inflata, (c) Globigerinoides ruber, (d) Globigerinoides sacculifer and (e) Globigerinella siphonifera. (e) Temperature at a water depth of $100 \mathrm{~m}$. The black dashed line in (f) indicates the $20^{\circ} \mathrm{C}$ isotherm which defines the modern maximum temperature of South Atlantic Central Water (Castelao et al., 2004), the water mass entering the photic zone in the upwelling sites of the southern Brazilian margin. The vertical yellow bar marks the interval with reversed radiocarbon ages listed in Table 1.

records from cores collected further north at the SBM such as GL-75 $\left(21^{\circ} 83^{\prime} \mathrm{S}, 40^{\circ} 01^{\prime} \mathrm{W}\right.$; Portilho-Ramos et al., 2015), GL-77 $\left(21^{\circ} 12^{\prime} \mathrm{S}, 40^{\circ} 02^{\prime} \mathrm{W}\right.$; Petró et al., 2016) and SAN 76 ( $24^{\circ} 26^{\prime} \mathrm{S}, 42^{\circ} 17^{\prime} \mathrm{W}$; Toledo et al., 2007), where G. bulloides ranged between $8 \%$ and $17 \%$, suggesting widespread cooling and elevated productivity at the SBM during the last glacial period relative to the modern oligotrophic conditions (Fig. 4a, b). During the last glacial period, the reduced abundance of non-upwelling species G. ruber $(25 \%-50 \%)$ and other warm and oligotrophic symbiont-bearing species such as G. sacculifer $(2.1 \%-10.4 \%)$ and G. siphonifera $(0.3 \%-$ $4.3 \%$ ) (Fig. 3) support the occurrence of cold, productive conditions promoted by upwelling. Simultaneously, lower temperatures at a water depth of $100 \mathrm{~m}\left(\leq 20^{\circ} \mathrm{C}\right)$ suggest that SACW may have been frequently located in the photic zone. The $20^{\circ} \mathrm{C}$ isotherm is used to track the boundary between tropical water and SACW (Castelao et al., 2004), and has been used as a proxy for the presence of SACW in the photic zone in the past (Portilho-Ramos et al., 2015; Lessa et al., 2017). It should be highlighted that a relative warming of thermocline waters observed after $30 \mathrm{ka} \mathrm{cal} \mathrm{BP}$ may be related to heat accumulation in the western South Atlantic associated with the glacial reduced mode of the Atlantic meridional overturning circulation (Santos et al., 2017) as well as increased transport of heat from Indian Ocean into South Atlantic via Agulhas leakage (Martínez-Méndez et al., 2010).

Enhanced glacial productivity in the SBM was recently reported by a $74 \mathrm{kyr}$ long record of dinoflagellate cysts from adjacent core GeoB2107-3 (27 $17^{\prime} \mathrm{S}, 46^{\circ} 45^{\prime \prime} \mathrm{W}$; Gu et al., 2017). The authors provided evidence of increased eutrophic conditions associated with more frequent northward intrusions of the PPW (Fig. 4d) (Gu et al., 2017). However, G. bulloides is virtually absent in surface sediments deposited under the influence of the PPW to the north of the Brazil-Malvinas Confluence (Chiessi et al., 2007). Thus, more frequent northward penetrations of the PPW in our study site are unlikely to explain the enhanced glacial abundance of G. bulloides. In addition, the abundance of the eutrophic environmental dinocysts and G. bulloides show different behavior during the last glacial period (Fig. 4a, d). The dinocysts increased in abundance between 54 and 74 and 14 and $40 \mathrm{ka} \mathrm{cal} \mathrm{BP}$, suggesting increased productivity related to frequent northward intrusions of the PPW, whereas the opposite is observed between 40 and $54 \mathrm{kacal} \mathrm{BP}$ (Fig. 4d), suggesting the reduced influence of the PPW and relatively low productivity (Gu et al., 2017). In contrast, the abundance of $G$. bulloides remained relatively high during the entire glacial with a decreasing trend after $30 \mathrm{kacal} \mathrm{BP}$ toward the Holocene (Figs. 3a, 4b). Furthermore, the enhanced abundance of $G$. bulloides during the last glacial period is also observed as far north as $21^{\circ} \mathrm{S}$ (i.e., core GL-75) (Fig. 4a) (Portilho-Ramos et al., 2015), which is unlikely to be explained by the continuous presence of the PPW (Möller et al., 2008).

\subsection{Modern and past seasonal productivity processes in the SBM}

Modern surface productivity in the SBM is seasonally modulated by two different processes that inject nutrients in the photic zone: (i) austral summer coastal and shelf-break upwelling (Campos et al., 2013); and (ii) austral winter northward intrusions of the PPW (Garcia and Garcia, 2008; Möller et al., 2008). During austral summer upwelling events, diatoms are the dominant group of the phytoplankton, accounting for $29 \%-90 \%$ of the phytoplankton density and $31 \%-$ $90 \%$ of the carbon biomass, while dinoflagellates are the 

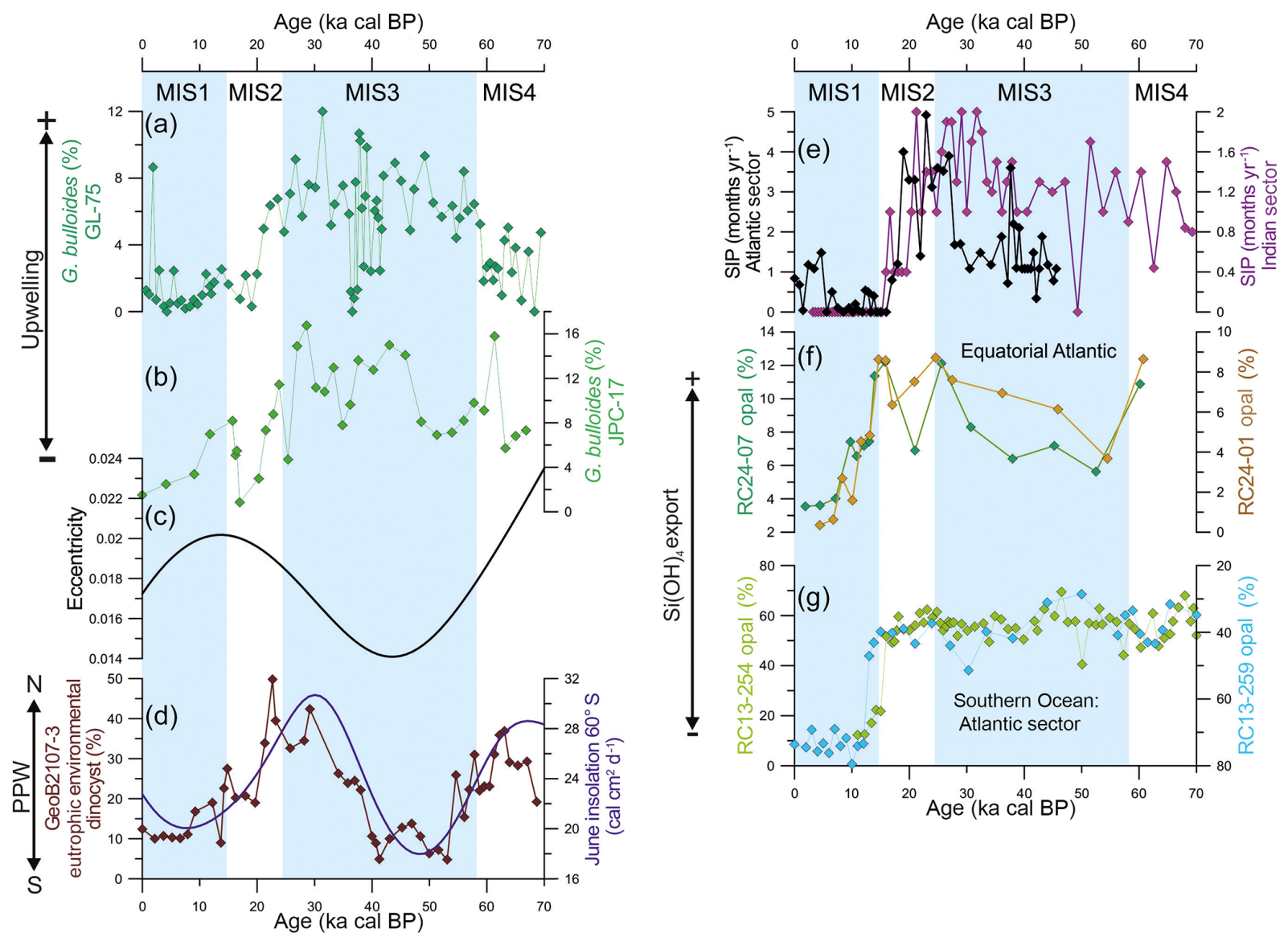

Figure 4. The mechanism behind the changes in productivity in the southern Brazilian margin over the last $70 \mathrm{kyr}$. Abundance of upwelling indicator species Globigerina bulloides from (a) core GL-75 $\left(21^{\circ} \mathrm{S}\right.$; Portilho-Ramos et al., 2015) and (b) core JPC-17 (27 ${ }^{\circ} \mathrm{S}$; this study). (c) Eccentricity of the Earth's orbit (Berger and Loutre, 1991). (d) The abundance of dinoflagellate cysts from core GeoB2107-3 (27 ${ }^{\circ} \mathrm{S}$ ) representing the influence of the Plata Plume Water in the southern Brazilian margin (Gu et al., 2017) and austral winter (June) insolation at $60^{\circ} \mathrm{S}$ (Berger and Loutre, 1991). (e) Antarctic sea ice presence (SIP) in the Atlantic sector core $\mathrm{TN} 057-13-\mathrm{PC} 4\left(53^{\circ} 20^{\prime} \mathrm{S}, 5^{\circ} 10^{\prime} \mathrm{W}\right.$; Shemesh et al., 2002) and Indian sector core SO136-111 (56 $40^{\prime} \mathrm{S}, 160^{\circ} 14^{\prime} \mathrm{W}$; Crosta et al., 2004) of the Southern Ocean derived from diatoms assemblage. (f) Opal content in the equatorial Atlantic upwelling off northwestern Africa from core $\mathrm{RC} 14-01\left(0.55^{\circ} \mathrm{N}, 13^{\circ} 65^{\prime} \mathrm{W}\right)$ and core RC24-07 $\left(1^{\circ} 33^{\prime} \mathrm{S}, 11^{\circ} 92^{\prime} \mathrm{W}\right)$ (Bradtmiller et al., 2007) as well as (g) in the Atlantic sector of the Southern Ocean from core $\mathrm{RC} 13-254\left(48^{\circ} 34^{\prime} \mathrm{S}, 5^{\circ} 34^{\prime} \mathrm{E}\right)$ and core RC13-259 (53⒌ $\left.53^{\prime} \mathrm{S}, 4^{\circ} 56^{\prime} \mathrm{W}\right)$ (Mortlock et al., 1991) as proxies for silicic acid transport toward low latitudes. Core RC13-254 is located to the north of the Antarctic Polar Zone (APZ), whereas core RC13-254 is located to the south of the APZ. Note the inverted (RC13-259) axis in (f).

dominant group during the austral winter associated with northward intrusions of the PPW (Brandini et al., 2014). We suggest that both taxa reveal different seasonal conditions during the last glacial period, with G. bulloides recording upwelling events during austral summer and dinoflagellates recording northward intrusions of the PPW during austral winter.

Prolonged winter-like conditions of prevalent alongshore southwesterly winds and frequent cold front passages during the last glacial period may have limited the SBM upwelling systems to a short period of austral summer-like conditions, as suggested by Portilho-Ramos et al. (2015). Furthermore, increased continental runoff (i.e., Itajaí River, Plata River and Patos/Mirim Lagoon complex) associated with en- hanced precipitation over southeast South America (Cruz et al., 2005; Wang et al., 2007) as well as a vigorous alongshore southwesterly winds were favorable for the northward penetration of the PPW. These conditions increased the abundance of dinocysts characteristic of eutrophic conditions in the SBM during the glacial (Gu et al., 2017). The lower sea level (Waelbroeck et al., 2002) may have caused the offshore displacement of the PPW to our core site location (Lantzsch et al., 2014).

Importantly, our reconstructed temperature at a water depth of $100 \mathrm{~m}$ indicates that SACW may have reached the photic zone during the last glacial period (Fig. 3f). Modern hydrographic data and model simulations show that shelfbreak upwelling in the SBM induced by the interaction of the 
BC with bottom topography occurs all year long but is modulated by the seasonal alongshore-wind direction (Campos et al., 2013; Brandini et al., 2018). Thus, a prolonged presence of the low-salinity PPW in the region may have increased the upper water stratification and suppressed the surfacing of SACW, favoring the proliferation of eutrophic dinocysts. In contrast, during short austral summer periods, the strengthening of both the alongshore northeasterly winds and the BC hampered the northward PPW migration, inducing the upwelling of SACW and creating favorable conditions for the proliferation of G. bulloides. Owing to the low resolution of core JPC-17, we cannot rule out an antiphase between the G. bulloides (i.e., core JPC-17) and the dinocyst (i.e., core GeoB2107-3) records that would assign the southwesterly winds and the associated northward penetration of PPW a key role in controlling the upwelling zones in the SBM during the last glacial period.

\subsection{Orbital forcing of SBM upwelling systems}

A recent study proposed orbitally forced changes in insolation (eccentricity) as a major mechanism modulating the intensification/deintensification and the expansion/contraction dynamics of the SBM upwelling zones (Lessa et al., 2017). In accordance with Lessa et al. (2017), an eccentricity maximum $(\geq 0.03)$ during MIS5 would have altered the seasonality of the wind regime by controlling the amplitude of austral summer and winter insolation and the South Atlantic subtropical high-pressure position. Thus, prolonged northeasterly winds during austral summer promoted intensification and expansion (from 24 to $28^{\circ} \mathrm{S}$ ) of the southeastern Brazil upwelling systems during MIS5. Conversely, an eccentricity minimum $(\leq 0.02)$ during the Holocene would result in weak northeasterly winds and a contraction and decrease in the intensity of these upwelling systems in comparison with MIS5 (Lessa et al., 2017).

However, the orbital mechanism proposed by Lessa et al. (2017) does not explain the intensified/expanded upwelling in the SBM during the last glacial period, as eccentricity was $\leq 0.02$ during the entire interval (Fig. $4 \mathrm{c}$ ). Interestingly, the dinocyst record from core GeoB2107-3 matches austral winter (June) insolation at $60^{\circ} \mathrm{S}$ very well over the last $70 \mathrm{kyr}$ (Fig. 4d), highlighting the close connection between dinocyst abundance and winter conditions through vigorous alongshore southwesterly winds and the increased presence of the PPW at our core site. Periods of increased austral winter insolation at $65^{\circ} \mathrm{S}$ may have steeped the thermal gradient between the high- and mid-latitudes in the Atlantic sector of the Southern Ocean, intensifying the alongshore southwesterly wind system and the northward incursion of PPW, thereby boosting the eutrophic environmental dinocyst productivity in the SBM.

\subsection{The silicic acid leakage hypothesis (SALH)}

In Sect. 5.1 and 5.2, we showed that $G$. bulloides and dinocysts record different seasonal productivity processes in the SMB. While austral winter productivity events were triggered by the more frequent northward intrusions of the PPW, it is not clear what could explain the occurrence of austral summer productivity events related to upwelling in the SBM.

We suggest that, rather than being driven by changes in upwelling intensity as observed during interglacial MIS5 (Portilho-Ramos et al., 2015; Lessa et al., 2017), the increased productivity may have been a result of the increased silicic acid $\left(\mathrm{Si}(\mathrm{OH})_{4}\right)$ content supplied by the glacial SACW. Several paleorecords and model experiments addressed the hypothesis that the increased export of dissolved $\mathrm{Si}(\mathrm{OH})_{4}$ preformed in the Southern Ocean fueled primary diatom productivity in low-latitude upwelling zones and continental margins during the last glacial period, the so called "silicic acid leakage hypothesis" (SALH) (DeMaster, 2002; Sarmiento et al., 2004; Bradtmiller et al., 2007; Matsumoto et al., 2014). The SALH postulates that during glacial periods, imposed sea ice around Antarctica displaced the zone of high diatom production to the north of the Antarctic Polar Front (APF), where thermocline waters (i.e., Subantarctic Mode Water, a precursor of SACW and Antarctic Intermediate Water - AAIW) is formed (Sarmiento et al., 2004; Bradtmiller et al., 2007; Abelmann et al., 2015). Thus, (unused) high-Si waters were exported from the Southern Ocean to the low-latitude world ocean, where diatom production increased at the expense of other types of phytoplankton (Sarmiento et al., 2004; Bradtmiller et al., 2007; Griffiths et al., 2013). In the Brazilian margin, the silicon isotopic composition $\left(8^{30} \mathrm{Si}\right)$ of sponge spicules from nearby core GeoB2107-3 indicates no substantial difference in the $\mathrm{Si}(\mathrm{OH})_{4}$ content of AAIW between the Last Glacial Maximum and the Holocene, which would contradict the SALH (Hendry et al., 2012). However, high-Si $(\mathrm{OH})_{4}$ pulses that occurred during the Younger Dryas and Heinrich stadials (Hendry et al., 2012) make the $\mathrm{Si}(\mathrm{OH})_{4}$ content of the average last glacial AAIW higher than that of the average Holocene AAIW. A significant increment of $\mathrm{Si}(\mathrm{OH})_{4}$ transported by AAIW was also observed in the western equatorial Atlantic at the onset of the last glacial (40-80 ka cal BP), which was not followed by enhanced surface productivity; this indicated that AAIW $\mathrm{Si}(\mathrm{OH})_{4}$ did not reach the photic zone (Griffiths et al., 2013). However, equatorial Atlantic upwelling zones are fed by SACW, and high glacial opal burial as a consequence of enhanced surface diatoms production due to intense upwelling is considered to be direct evidence of the SALH (Bradtmiller et al., 2007). Indeed, SACW is the major conduit for sub-Antarctic thermocline waters involved in the SALH (Sarmiento et al., 2004) and have great potential to boost primary production in the SBM (Campos et al., 2000).

Currently, diatoms dominate the phytoplankton in the SBM during austral summer SACW upwelling (Brandini et 
al., 2014) and are an important component of the diet of the symbiotic-barren $G$. bulloides, which can alternatively feed on zooplankton (i.e., copepods) (Sautter and Thunell, 1991; Thunell and Sautter, 1992; Schiebel and Hemleben, 2017). Within age model uncertainties (also including the radiocarbon reversals in our core) and considering the different temporal resolution of the records, the glacial high abundance of G. bulloides in core JPC-17 matches well with the high biogenic opal percentage in cores RC24-01 and RC2407 from the equatorial upwelling off northwestern Africa (Bradtmiller et al., 2007) as well as core RC13-254, to the north of the APF Front (Atlantic sector) (Mortlock et al., 1991) (Fig. 4b, f, g). It is noteworthy that SACW also receives contributions from the Indian Ocean via Agulhas leakage (warm water route; Donners and Drijfhout, 2004), where the production of opal (north of the APF) and export of silicic acid remained high over the entire last glaciation (Dezileau et al., 2003). We suggest that G. bulloides in the SBM may have benefited the silicic acid-induced diatom blooms directly by feeding diatoms and/or indirectly by preying on other zooplankton that also feed on diatoms. Thus, the increased abundance of $G$. bulloides in the SBM during the last glacial period was related to upwelling-driven high productivity during short austral summer periods, as previously suggested in Portilho-Ramos et al. (2015). In contrast, prolonged austral winter conditions with vigorous alongshore southwesterly winds as well as increased precipitation over southeastern South America (Cruz et al., 2005; Wang et al., 2007) increased the northward penetration of the PPW leading to enhanced eutrophic environmental dinocyst productivity during the last glaciation (Gu et al., 2017). In combination, both processes may have boosted biological primary productivity throughout the year during the last glacial period. This is supported by the enhanced abundance of the deep-dwelling herbivorous planktonic foraminifera species Globorotalia inflata (Schiebel and Hemleben, 2017) that calcifies between water depths of 200 and $400 \mathrm{~m}$ (Chiessi et al., 2007) and would have benefited from grazing the increased amount of sinking organic particles.

\subsection{Post-glacial conditions}

After the Last Glacial Maximum, the abundance of G. bulloides and eutrophic dinocysts decrease until the onset of the Holocene, suggesting decreased regional productivity and more oligotrophic conditions in comparison with the last glacial period (Fig. 4b, d). The presence of oligotrophic conditions is supported by the increased abundance of the tropical symbiont-bearing species G. ruber $(37 \%-52 \%)$, G. sacculifer (6\%-8.8\%) and G. siphonifera $(6.3 \%-7.5 \%)$ (Fig. 3). The low abundance of $G$. inflata also suggests oligotrophic conditions during the Holocene (Fig. 3b). Despite the favorable conditions for upwelling in the SBM during the Holocene (i.e., occurrence of alongshore northeasterly winds and a strong BC; Chiessi et al., 2014; Portilho-Ramos et al., 2015; Lessa et al., 2017), upwelling productivity may have been hampered by the reduced export of preformed silicic acid through SACW (Fig. 4f, g). This is supported by the substantial decrease of biogenic opal in equatorial upwelling cores RC24-01 and RC24-07 after $15 \mathrm{kacal} \mathrm{BP}$ (Fig. 4f; Bradtmiller et al., 2007). Indeed, the retraction of Antarctic sea ice displaced the zone of enhanced biogenic opal production to the south of the APF, retaining the excess of silicic acid and opal burial in the Southern Ocean (Sarmiento et al., 2004; Bradtmiller et al., 2007) as evidenced by increased Holocene biogenic opal to the south of the APF at core RC13-259 (Fig. 4g; Mortlock et al., 1991). In addition, low austral winter insolation at $65^{\circ} \mathrm{S}$ and reduced sea ice may have decrease the thermal gradient between the high- and mid-latitudes in the Atlantic sector of the Southern Ocean and consequently weakened the alongshore southwesterly winds in the SBM, inhibiting the northward intrusions of the PPW. Simultaneously, the high sea level stand modified the SBM morphology increasing the width of the southern Brazilian shelf and displacing the core of the upwelling zone to the inner shelf off Cape Santa Marta, where it is controlled by local factors such as the coastal wind system (Möller et al., 2008; Campos et al., 2013). The high temperatures at a water depth of $100 \mathrm{~m}$ from core JPC-17 (Fig. 3f) support this hypothesis, suggesting that the SACW was not frequently in the photic zone at the core location.

\section{Conclusions}

In this study we used planktonic foraminifera assemblage information and associated temperatures at a water depth of $100 \mathrm{~m}$ to discuss changes in productivity on the southern Brazilian margin over the last $70 \mathrm{kyr}$. The enhanced abundance of the upwelling indicator Globigerina bulloides $(12 \%-16 \%)$ in addition to the reduced abundance of oligotrophic species and subsurface temperatures lower than $20^{\circ} \mathrm{C}$ suggest the occurrence of upwelling off Cape Santa Marta during the last glacial period. We suggest that rather than being driven by changes in upwelling intensity, the increased productivity may have been a result of increased silicic acid export from the Southern Ocean via South Atlantic Central Water. Our results show that orbital forcing did not have a major influence on changes in upwelling during the last glacial period. We further show that more frequent northward intrusions of Plata Plume Water modulated by austral winter insolation at $60^{\circ} \mathrm{S}$ through enhanced alongshore southwesterly winds boosted austral winter productivity at the SBM. Thus, a productive upwelling during short austral summer events and the prolonged presence of Plata Plume Water during austral winter enhanced the biological productivity year-round in the SBM during the last glacial period relative to modern conditions. After the Last Glacial Maximum, the low silicic acid content in thermocline waters decreased the productivity of the upwelling, while lower 
austral winter insolation at $60^{\circ} \mathrm{S}$ and associated weakened southwesterly winds reduced the presence of the Plata Plume Water in the SBM. In addition, last deglaciation sea level rise may have modified the geomorphology of the SBM limiting the upwelling system to the coast, south to Cape Santa Marta.

Data availability. The data reported here will be archived in the World Data Center PANGAEA (https://doi.pangaea.de/10.1594/ PANGAEA.902040) (last access: 24 May 2019) (Portilho-Ramos et al., 2019).

Author contributions. RdCPR and CMC designed the study. RdCPR and TMLP analyzed the planktonic foraminifera assemblage. RdCPR and CMC wrote the paper. RdCPR performed the modern analogue technique. RdCPR and CFB performed age modeling. All authors contributed to the interpretation of the data.

Competing interests. The authors declare that they have no conflict of interest.

Acknowledgements. We thank the two anonymous referees for their constructive comments. We are grateful to Delia Oppo and William B. Curry from Woods Hole Oceanographic Institute, United States, for providing the oxygen isotope data from core JPC-17. Rodrigo da Costa Portilho-Ramos is thankful for a PNPD (Programa Nacional de Pós-doutorado) scholarship from CAPES (Coordenação de Aperfeiçoamento de Pessoal de Nível Superior). Tainã Marcos Lima Pinho is grateful for a PIBIC (Programa Institucional de Bolsas de Iniciação Científica) scholarship from $\mathrm{CNPq}$ (Conselho Nacional de Desenvolvimento Científico e Tecnológico; 2017-482). Cristiano Mazur Chiessi acknowledges financial support from FAPESP (Fundação de Amparo à Pesquisa do Estado de São Paulo; grant no. 2012/17517-3), CAPES (grant nos. 1976/2014 and 564/2015) and CNPq (grant nos. 302607/2016-1 and 422255/2016$5)$.

Financial support. The article processing charges for this openaccess publication were covered by the University of Bremen.

Review statement. This paper was edited by Arne Winguth and reviewed by two anonymous referees.

\section{References}

Abelmann, A., Gersonde, R., Knorr, G., Zhang, X., Chapligin, B., Maier, E., Esper, O., Friedrichsen, H., Lohmann, G., Meyer, H., and Tiedemann, R.: The seasonal sea-ice zone in the glacial Southern Ocean as a carbon sink, Nat. Commun., 6, 8136, https://doi.org/10.1038/ncomms9136, 2015.

Abrantes, F., Cermeno, P., Lopes, C., Romero, O., Matos, L., Van Iperen, J., Rufino, M., and Magalhães, V.: Diatoms Si up- take capacity drives carbon export in coastal upwelling systems, Biogeosciences, 13, 4099-4109, https://doi.org/10.5194/bg-134099-2016, 2016.

Aguiar, A. L., Cirano, M., Pereira, J., and Marta-Almeida, M.: Upwelling processes along a western boundary current in the Abrolhos-Campos region of Brazil, Cont. Shelf Res., 85, 42-59, https://doi.org/10.1016/j.csr.2014.04.013, 2014.

André, A., Weiner, A., Quillévéré, F., Aurahs, R., Morard, R., Douady, C. J., de Garidel-Thoron, T., Escarguel, G., de Vargas, C., and Kucera, M.: The cryptic and the apparent reversed: lack of genetic differentiation within the morphologically diverse plexus of the planktonic foraminifer Globigerinoides sacculifer, Paleobiology, 39, 21-39, https://doi.org/10.1666/00948373-39.1.21, 2013.

Berger, A. and Loutre, M. F.: Insolation values for the climate of the last 10 million years, Quaternary Sci. Rev., 10, 297-317, https://doi.org/10.1016/0277-3791(91)90033-Q, 1991.

Bianchi, A. A., Bianucci, L., Piola, A. R., Pino, D. R., Schloss, I., Poisson, A., and Balestrini, C. F.: Vertical stratification and airsea $\mathrm{CO}_{2}$ fluxes in the Patagonian shelf, J. Geophys. Res., 110, 1-10, https://doi.org/10.1029/2004JC002488, 2005.

Blaauw, M. and Christen, J. A.: Flexible paleoclimate age-depth models using an autoregressive gamma process, Bayesian Anal., 6, 457-474, https://doi.org/10.1214/11-BA618, 2011.

Bradtmiller, L. I., Anderson, R. F., Fleisher, M. Q., and Burckle, L. H.: Opal burial in the equatorial Atlantic Ocean over the last $30 \mathrm{ka}$ : Implications for glacial-interglacial changes in the ocean silicon cycle, Paleoceanography, 22, PA4216, https://doi.org/10.1029/2007PA001443, 2007.

Brandini, F. P., Nogueira, M., Simião, M., Codina, J. C. U., and Almeida Noernberg, M.: Deep chlorophyll maximum and plankton community response to oceanic bottom intrusions on the continental shelf in the South Brazilian Bight, Cont. Shelf Res., 89, 61-75, https://doi.org/10.1016/j.csr.2013.08.002, 2014.

Brandini, F. P., Tura, P. M., and Santos, P. P. G. M.: Ecosystem responses to biogeochemical fronts in the South Brazil Bight, Prog. Oceanogr., 164, 52-62, https://doi.org/10.1016/j.pocean.2018.04.012, 2018.

Campos, E. J. D., Velhote, D., and da Silveira, I. C. A.: Shelf break upwelling driven by Brazil Current Cyclonic Meanders, Geophys. Res. Lett., 27, 751-754, https://doi.org/10.1029/1999GL010502, 2000.

Campos, P. C., Möller, O. O., Piola, A. R., and Palma, E. D.: Seasonal variability and coastal upwelling near Cape Santa Marta (Brazil), J. Geophys. Res.-Oceans, 118, 1420-1433, https://doi.org/10.1002/jgrc.20131, 2013.

Castelao, R. M., Campos, E. J. D., and Miller, J. L.: A Modelling Study of Coastal Upwelling Driven by Wind and Meanders of the Brazil Current, J. Coastal Res., 203, 662-671, 2004.

Chiessi, C. M., Ulrich, S., Mulitza, S., Pätzold, J., and Wefer, G.: Signature of the Brazil-Malvinas Confluence (Argentine Basin) in the isotopic composition of planktonic foraminifera from surface sediments, Mar. Micropaleontol., 64, 52-66, https://doi.org/10.1016/j.marmicro.2007.02.002, 2007.

Chiessi, C. M., Mulitza, S., Groeneveld, J., Silva, J. B., Campos, M. C., and Gurgel, M. H. C.: Variability of the Brazil Current during the late Holocene, Palaeogeogr. Palaeocl., 415, 28-36, https://doi.org/10.1016/j.palaeo.2013.12.005, 2014. 
Crosta, X., Sturm, A., Armand, L., and Pichon, J.-J.: Late Quaternary sea ice history in the Indian sector of the Southern Ocean as recorded by diatom assemblages, Mar. Micropaleontol., 50, 209223, https://doi.org/10.1016/S0377-8398(03)00072-0, 2004.

Cruz, F. W., Burns, S. J., Karmann, I., Sharp, W. D., Vuille, M., Cardoso, A. O., Ferrari, J. A., Dias, P. L. S., and Viana, O.: Insolation-driven changes in atmospheric circulation over the past 116000 years in subtropical Brazil, Nature, 434, 63-6, https://doi.org/10.1038/nature03365, 2005.

Curry, W. B. and Oppo, D. W.: Glacial water mass geometry and the distribution of $\delta^{13} \mathrm{C}$ of $\Sigma \mathrm{CO}_{2}$ in the western Atlantic Ocean, Paleoceanography, 20, PA1017, https://doi.org/10.1029/2004PA001021, 2005.

DeMaster, D. J.: The accumulation and cycling of biogenic silica in the Southern Ocean: Revisiting the marine silica budget, DeepSea Res. Pt. II, 49, 3155-3167, https://doi.org/10.1016/S09670645(02)00076-0, 2002.

de Vargas, C., Bonzon, M., Rees, N. W., Pawlowski, J., and Zaninetti, L.: A molecular approach to biodiversity and biogeography in the planktonic foraminifer Globigerinella siphonifera (d'Orbigny), Mar. Micropaleontol., 45, 101-116, https://doi.org/10.1016/S0377-8398(02)00037-3, 2002.

Dezileau, L., Reyss, J. L., and Lemoine, F.: Late Quaternary changes in biogenic opal fluxes in the Southern Indian Ocean, Mar. Geol., 202, 143-158, https://doi.org/10.1016/S00253227(03)00283-4, 2003.

Donners, J. and Drijfhout, S. S.: The Lagrangian View of South Atlantic Interocean Exchange in a Global Ocean Model Compared with Inverse Model Results, J. Phys. Oceanogr., 34, 1019-1035, https://doi.org/10.1175/15200485(2004)034<1019:TLVOSA>2.0.CO;2, 2004.

Ericson, D. B. and Wollin, G.: Pleistocene Climates and Chronology in Deep-Sea Sediments, Science, 162, 1227-1234, https://doi.org/10.1126/science.162.3859.1227, 1968.

Garcia, C. A. E. and Garcia, V. M. T.: Variability of chlorophyll-a from ocean color images in the La Plata continental shelf region, Cont. Shelf Res., 28, 1568-1578, https://doi.org/10.1016/j.csr.2007.08.010, 2008.

Godad, S. P., Naidu, P. D., and Malmgren, B. A.: Sea surface temperature changes during May and August in the western Arabian Sea over the last $22 \mathrm{kyr}$ : Implications as to shifting of the upwelling season, Mar. Micropaleontol., 78, 25-29, https://doi.org/10.1016/j.marmicro.2010.09.006, 2011.

Griffiths, J. D., Barker, S., Hendry, K. R., Thornalley, D. J. R., van de Flierdt, T., Hall, I. R., and Anderson, R. F.: Evidence of silicic acid leakage to the tropical Atlantic via Antarctic Intermediate Water during Marine Isotope Stage 4, Paleoceanography, 28, 307-318, https://doi.org/10.1002/palo.20030, 2013.

Gu, F., Zonneveld, K. A. F., Chiessi, C. M., Arz, H. W., Pätzold, J., and Behling, H.: Long-term vegetation, climate and ocean dynamics inferred from a 73500 years old marine sediment core (GeoB2107-3) off southern Brazil, Quaternay Sci. Rev., 172, 5571, https://doi.org/10.1016/j.quascirev.2017.06.028, 2017.

Hendry, K. R., Robinson, L. F., Meredith, M. P., Mulitza, S., Chiessi, C. M., and Arz, H.: Abrupt changes in high-latitude nutrient supply to the Atlantic during the last glacial cycle, Geology, 40, 123-126, https://doi.org/10.1130/G32779.1, 2012.

Ito, R. G., Garcia, C. A. E., and Tavano, V. M.: Net sea-air $\mathrm{CO}_{2}$ fluxes and modelled $p \mathrm{CO}_{2}$ in the south- western subtropical Atlantic continental shelf during spring 2010 and summer 2011, Cont. Shelf Res., 119, 68-84, https://doi.org/10.1016/J.CSR.2016.03.013, 2016.

Juggins, S.: C2 user guide: Software for ecological and palaeoecological data analysis and visualization, Newcastle University, Newcastle, UK, 2007.

Kucera, M., Rosell-Melé, A., Schneider, R., Waelbroeck, C., and Weinelt, M.: Multiproxy approach for the reconstruction of the glacial ocean surface (MARGO), Quaternary Sci. Rev., 24, 813819, https://doi.org/10.1016/j.quascirev.2004.07.017, 2005a.

Kucera, M., Weinelt, M., Kiefer, T., Pflaumann, U., Hayes, A., Weinelt, M., Chen, M.-T., Mix, A. C., Barrows, T. T., Cortijo, E., Duprat, J., Juggins, S., and Waelbroeck, C.: Reconstruction of sea-surface temperatures from assemblages of planktonic foraminifera: multi-technique approach based on geographically constrained calibration data sets and its application to glacial Atlantic and Pacific Oceans, Quaternary Sci. Rev., 24, 951-998, https://doi.org/10.1016/j.quascirev.2004.07.014, 2005b.

Lantzsch, H., Hanebuth, T. J. J., Chiessi, C. M., Schwenk, T., and Violante, R. A.: The high-supply, current-dominated continental margin of southeastern South America during the late Quaternary, Quaternary Res., 81, 339-354, https://doi.org/10.1016/j.yqres.2014.01.003, 2014.

Lessa, D. V. de O., Portilho-Ramos, R. C., Barbosa, C. F., da Silva, A. R., Belem, A., Turcq, B., Albuquerque, A. L., and Ramos, R. P.: Planktonic foraminifera in the sediment of a western boundary upwelling system off Cabo Frio, Brazil, Mar. Micropaleontol., 106, 55-68, https://doi.org/10.1016/j.marmicro.2013.12.003, 2014.

Lessa, D. V. O., Santos, T. P., Venancio, I. M., and Albuquerque, A. L. S.: Offshore expansion of the Brazilian coastal upwelling zones during Marine Isotope Stage 5, Global Planet. Change, 158, 13-20, https://doi.org/10.1016/j.gloplacha.2017.09.006, 2017.

Lisiecki, L. E. and Stern, J. V.: Regional and global benthic $\delta^{18} \mathrm{O}$ stacks for the last glacial cycle, Paleoceanography, 31, 13681394, https://doi.org/10.1002/2016PA003002, 2016.

Locarnini, R. A., Mishonov, A. V., Antonov, J. I., Boyer, T. P., Garcia O. H. E., Baranova, O. K., and Zweng, M. M.: World ocean database 2009, vol 1: temperature, US government printing office, Washington, DC, USA, 2010.

Martínez-Méndez, G., Zahn, R., Hall, I. R., Peeters, F. J. C., Pena, L. D., Cacho, I., and Negre, C.: Contrasting multiproxy reconstructions of surface ocean hydrography in the Agulhas Corridor and implications for the Agulhas Leakage during the last 345000 years, Paleoceanography, 25, PA4227, https://doi.org/10.1029/2009PA001879, 2010.

Matsumoto, K., Chase, Z., and Kohfeld, K.: Different mechanisms of silicic acid leakage and their biogeochemical consequences, Paleoceanography, 29, 238-254, https://doi.org/10.1002/2013PA002588, 2014.

Mohtadi, M., Max, L., Hebbeln, D., Baumgart, A., Krück, N., and Jennerjahn, T.: Modern environmental conditions recorded in surface sediment samples off $\mathrm{W}$ and SW Indonesia: Planktonic foraminifera and biogenic compounds analyses, Mar. Micropaleontol., 65, 96-112, https://doi.org/10.1016/j.marmicro.2007.06.004, 2007.

Möller, O. O., Piola, A. R., Freitas, A. C., and Campos, E. J. D.: The effects of river discharge and seasonal winds on the shelf off 
southeastern South America, Cont. Shelf Res., 28, 1607-1624, https://doi.org/10.1016/j.csr.2008.03.012, 2008.

Morey, A. E., Mix, A. C., and Pisias, N. G.: Planktonic foraminiferal assemblages preserved in surface sediments correspond to multiple environment variables, Quaternary Sci. Rev., 24, 925-950, https://doi.org/10.1016/j.quascirev.2003.09.011, 2005.

Mortlock, R. A., Charles, C. D., Froelich, P. N., Zibello, M. A., Saltzman, J., Hays, J. D., and Burckle, L. H.: Evidence for lower productivity in the Antarctic Ocean during the last glaciation, Nature, 351, 220-223, https://doi.org/10.1038/351220a0, 1991.

Muller-Karger, F. E., Varela, R., Thunell, R., Luerssen, R., Hu, C., and Walsh, J. J.: The importance of continental margins in the global carbon cycle, Geophys. Res. Lett., 32, 1-4, https://doi.org/10.1029/2004GL021346, 2005.

Paillard, D., Labeyrie, L., and Yiou, P.: Macintosh Program performs time-series analysis, Eos, Transactions American Geophysical Union, 77, p. 379, https://doi.org/10.1029/96EO00259, 1996.

Peeters, F. J. C., Brummer, G. J. A., and Ganssen, G.: The effect of upwelling on the distribution and stable isotope composition of Globigerina bulloides and Globigerinoides ruber (planktic foraminifera) in modern surface waters of the NW Arabian Sea, Global Planet. Change, 34, 269-291, https://doi.org/10.1016/S0921-8181(02)00120-0, 2002.

Petró, S. M., Pivel, M. A. G., Coimbra, J. C., and Mizusaki, A. M. P.: Paleoceanographic changes through the last $130 \mathrm{ka}$ in the western South Atlantic based on planktonic Foraminifera, Rev. Bras. Paleontolog., 19, 3-14, https://doi.org/10.4072/rbp.2016.1.01, 2016.

Portilho-Ramos, R. C., Ferreira, F., Lago, L. C., Da Silva, A. G. V., Jaworski, K. S., and Toledo, M. B.: Globorotalia crassaformis optimum event: a new late Quaternary biostratigraphic marker for the southeastern Brazilian margin, Palaios, 29, 578-593, https://doi.org/10.2110/palo.2013.097, 2014a.

Portilho-Ramos, R. C., Barbosa, C. F., and Rios-Netto, A. M.: Planktonic foraminiferal variations in the southwestern Atlantic since the last glacial-interglacial cycle, Palaios, 29, 38-44, https://doi.org/10.2110/palo.2012.104, 2014b.

Portilho-Ramos, R. C., Ferreira, F., Calado, L., Frontalini, F., and de Toledo, M. B.: Variability of the upwelling system in the southeastern Brazilian margin for the last 110000 years, Global Planet. Change, 135, 179-189, https://doi.org/10.1016/j.gloplacha.2015.11.003, 2015.

Portilho-Ramos, R. C., Pinho, M. R., Chiessi, C. M., and Barbosa, C. F.: Planktonic foraminifera assemblage, MAT-derived sea surface temperature and Cibicides spp. oxygen isotopes, PANGAEA, available at: https://doi.pangaea.de/10.1594/PANGAEA. 902040 (unpublished dataset), last access: 24 May 2019.

Reimer, P. J., Bard, E., Bayliss, A., Beck, J. W., Blackwell, P. G., Ramsey, C. B., Buck, C. E., Cheng, H., Edwards, R. L., Friedrich, M., Grootes, P. M., Guilderson, T. P., Haflidason, H., Hajdas, I., Hatté, C., Heaton, T. J., Hoffmann, D. L., Hogg, A. G., Hughen, K. A., Kaiser, K. F., Kromer, B., Manning, S. W., Niu, M., Reimer, R. W., Richards, D. A., Scott, E. M., Southon, J. R., Staff, R. A., Turney, C. S. M., and van der Plicht, J.: IntCal13 and Marine13 Radiocarbon Age Calibration Curves 0-50000 Years cal BP, Radiocarbon, 55, 1869-1887, https://doi.org/10.2458/azu_js_rc.55.16947, 2013.
Rodrigues, R. R. and Lorenzzetti, J. A.: A numerical study of the effects of bottom topography and coastline geometry on the Southeast Brazilian coastal upwelling, Cont. Shelf Res., 21, 371-394, https://doi.org/10.1016/S0278-4343(00)00094-7, 2001.

Rodrigues, S. V., Marinho, M. M., Jonck, C. C. C., Gonçalves, E. S., Brant, V. F., Paranhos, R., Curbelo, M. P., and Falcão, A. P.: Phytoplankton community structures in shelf and oceanic waters off southeast Brazil $\left(20-25^{\circ} \mathrm{S}\right)$, as determined by pigment signatures, Deep-Sea Res. Pt. I, 88, 47-62, https://doi.org/10.1016/j.dsr.2014.03.006, 2014.

Salgueiro, E., Naughton, F., Voelker, A. H. L., Abreu, L. De and Alberto, A.: Past circulation along the western Iberian margin?: a time slice vision from the Last Glacial to the Holocene, Quaternary Sci. Rev., 106, 316-329, https://doi.org/10.1016/j.quascirev.2014.09.001, 2014.

Santos, T. P., Lessa, D. O., Venancio, I. M., Chiessi, C. M., Mulitza, S., Kuhnert, H., Govin, A., Machado, T., Costa, K. B., Toledo, F., Dias, B. B., and Albuquerque, A. L. S.: Prolonged warming of the Brazil Current precedes deglaciations, Earth Planet. Sc. Lett., 463, 1-12, https://doi.org/10.1016/j.eps1.2017.01.014, 2017.

Sarmiento, J. L., Gruber, N., Brzezinski, M. A., and Dunne, J. P.: High-latitude controls of thermocline nutrients and low latitude biological productivity., Nature, 427, 56-60, https://doi.org/10.1038/nature10605, 2004.

Sautter, L. R. and Thunell, R. C.: Planktonic foraminiferal response to upwelling and seasonal hydrographic conditions; sediment trap results from San Pedro Basin, Southern California Bight, J. Foramin. Res., 21, 347-363, https://doi.org/10.2113/gsjfr.21.4.347, 1991.

Schiebel, R. and Hemleben, C.: Ecology, in Planktic Foraminifers in the Modern Ocean, Springer Berlin Heidelberg, Berlin, Heidelberg, Germany, 209-230, 2017.

Shemesh, A., Hodell, D., Crosta, X., Kanfoush, S., Charles, C., and Guilderson, T.: Sequence of events during the last deglaciation in Southern Ocean sediments and Antarctic ice cores, Paleoceanography, 17, 81-87, https://doi.org/10.1029/2000PA000599, 2002.

Stainforth, R. M., Lamb, J. L., Luterbacher, H., Beard, J. H., and Jeffords, R. M.: Cenozoic Planktonic Foraminiferal Zonation and Characteristics of Index Formsle, The Paleontological Institute, The University of Kansas, Kansas, available at: http://hdl.handle. net/1808/3836 (last access: 14 March 2017), 1975.

Tessin, A. C. and Lund, D. C.: Isotopically depleted carbon in the mid-depth South Atlantic during the last deglaciation, Paleoceanography, 28, 296-306, https://doi.org/10.1002/palo.20026, 2013.

Thunell, R. and Sautter, L. R.: Planktonic foraminiferal faunal and stable isotopic indices of upwelling: a sediment trap study in the San Pedro Basin, Southern California Bight, Geol. Soc. Spec. Publ., 64, 77-91, https://doi.org/10.1144/GSL.SP.1992.064.01.05, 1992.

Toledo, F. A. L., Cachão, M., Costa, K. B., and Pivel, M. A. G.: Planktonic foraminifera, calcareous nannoplankton and ascidian variations during the last $25 \mathrm{kyr}$ in the Southwestern Atlantic: A paleoproductivity signature?, Mar. Micropaleontol., 64, 67-79, https://doi.org/10.1016/j.marmicro.2007.03.001, 2007.

Turner, J. T.: Zooplankton fecal pellets, marine snow, phytodetritus and the ocean's biological pump, Prog. Oceanogr., 130, 205-248, https://doi.org/10.1016/j.pocean.2014.08.005, 2015. 
Volbers, A. N. A. and Henrich, R.: Calcium carbonate corrosiveness in the South Atlantic during the Last Glacial Maximum as inferred from changes in the preservation of Globigerina bulloides: A proxy to determine deep-water circulation patterns?, Mar. Geol., 204, 43-57, https://doi.org/10.1016/S00253227(03)00372-4, 2004.

Waelbroeck, C., Labeyrie, L., Michel, E., Duplessy, J. C., McManus, J. F., Lambeck, K., Balbon, E., and Labracherie, M.: Sealevel and deep water temperature changes derived from benthic foraminifera isotopic records, Quaternary Sci. Rev., 21, 295-305, https://doi.org/10.1016/S0277-3791(01)00101-9, 2002.
Wang, D., Gouhier, T. C., Menge, B. A., and Ganguly, A. R.: Intensification and spatial homogenization of coastal upwelling under climate change, Nature, 518, 390-394, https://doi.org/10.1038/nature14235, 2015.

Wang, X., Auler, A. S., Edwards, R. L., Cheng, H., Ito, E., Wang, Y., Kong, X., and Solheid, M.: Millennial-scale precipitation changes in southern Brazil over the past 90000 years, Geophys. Res. Lett., 34, L23701, https://doi.org/10.1029/2007GL031149, 2007. 